\title{
s-Triazine: A Privileged Structure for Drug Discovery and Bioconjugation
}

\author{
Anamika Sharma ${ }^{1,2} \mathbb{D}$, Rotimi Sheyi ${ }^{1}$, Beatriz G. de la Torre ${ }^{1,2} \mathbb{D}$, Ayman El-Faham ${ }^{3,4, *(\mathbb{D})}$ \\ and Fernando Albericio 1,3,5,6,*iD
}

1 Peptide Science Laboratory, School of Chemistry and Physics, University of KwaZulu-Natal, Durban 4001, South Africa; anamika.aug14@gmail.com (A.S.); ebenrotex4fun@gmail.com (R.S.); garciadelatorreb@ukzn.ac.za (B.G.d.1.T.)

2 KwaZulu-Natal Research Innovation and Sequencing Platform (KRISP), School of Laboratory Medicine and Medical Sciences, College of Health Sciences, University of KwaZulu-Natal, Durban 4041, South Africa

3 Department of Chemistry, College of Science, King Saud University, P.O. Box 2455, Riyadh 11451, Saudi Arabia

4 Chemistry Department, Faculty of Science, Alexandria University, P.O. Box 426, Ibrahimia, Alexandria 12321, Egypt

5 Institute for Advanced Chemistry of Catalonia (IQAC-CSIC), 08034 Barcelona, Spain

6 CIBER-BBN (Networking Centre on Bioengineering, Biomaterials and Nanomedicine) and Department of Organic Chemistry, University of Barcelona, 08028 Barcelona, Spain

* Correspondence: aymanel_faham@hotmail.com (A.E.-F.); albericio@ukzn.ac.za (F.A.)

check for updates

Citation: Sharma, A.; Sheyi, R.; de la Torre, B.G.; El-Faham, A.; Albericio, F. s-Triazine: A Privileged Structure for Drug Discovery and Bioconjugation. Molecules 2021, 26, 864. https://doi.org/10.3390/ molecules 26040864

Academic Editors: Julio A. Seijas Vázquez and María Ángeles Castro

Received: 4 January 2021

Accepted: 4 February 2021

Published: 6 February 202

Publisher's Note: MDPI stays neutral with regard to jurisdictional claims in published maps and institutional affiliations.

Copyright: (C) 2021 by the authors Licensee MDPI, Basel, Switzerland. This article is an open access article distributed under the terms and conditions of the Creative Commons Attribution (CC BY) license (https:// creativecommons.org/licenses/by/ $4.0 /)$.

\begin{abstract}
This review provides an overview of the broad applicability of s-triazine. Our many years working with this intriguing moiety allow us to discuss its wide activity spectrum (inhibition against MAO-A and -B, anticancer/antiproliferative and antimicrobial activity, antibacterial activity against MDR clinical isolates, antileishmanial agent, and use as drug nano delivery system). Most of the compounds addressed in our studies and those performed by other groups contain only $N$-substitution. Exploiting the concept of orthogonal chemoselectivity, first described by our group, we have successfully incorporated different nucleophiles in different orders into s-triazine core for application in peptides/proteins at a temperature compatible with biological systems.
\end{abstract}

Keywords: s-triazine; nucleophiles; azide; orthogonal chemoselectivity

\section{Introduction}

1,3,5-Triazine as s-triazine is an extensively studied privileged structure in medicinal chemistry [1-5]. 2,4,6-Trichloro-1,3,5-triazine (TCT) is the starting core to afford several s-triazine derivatives, taking advantage of its low cost and easy manipulation of three independent, readily tunable ring positions, which facilitates the sequential nucleophilic substitutions reactions with almost all types of nucleophiles ( $\mathrm{O}, \mathrm{O}$ and $\mathrm{N})$ [6-12]. Figure 1 shows the typical order of nucleophile incorporation onto TCT. The incorporation of the first nucleophile can be performed at $0-5{ }^{\circ} \mathrm{C}$, while the second one requires room temperature, and the third heating or reflux [13-15]. The reactivity of the s-triazine ring decreases upon substitution with different nucleophiles due to a gain of $\pi$-orbital electron density, thereby reducing the effectiveness of further nucleophilic substitution reactions under similar conditions and thus requiring a higher temperature for further substitutions $[8,16]$.

s-Triazine is extensively studied because of its wide applications in biological systems as an antibacterial, antiviral, anticancer, and antifungal agent, etc. $[1,5,17,18]$. Several commercial drugs contain the s-triazine core (Figure 2) [3,5]. Apart from their application as pharmacophores and in medicinal chemistry, s-triazine derivatives are useful as organic reagents, energetics, and new materials (dendrimers, supra-molecular aggregates, etc.) $[4,12,19,20]$. 


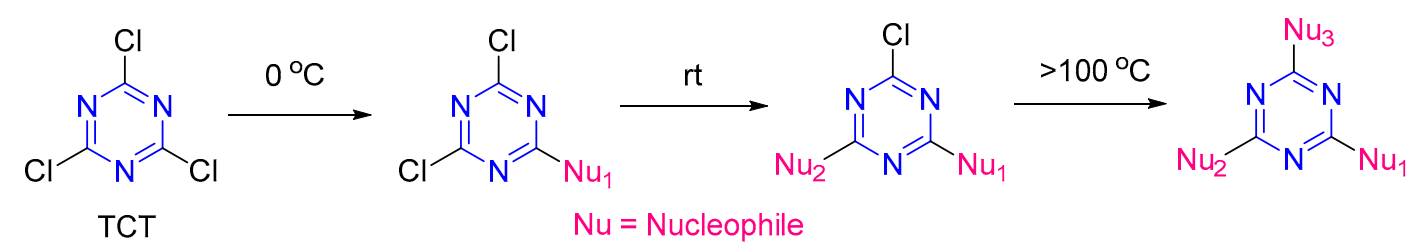

Figure 1. 2,4,6-Trichloro-1,3,5-triazine (TCT) reactivity toward the nucleophilic substitution reaction.<smiles>C1CC1N1CC1</smiles>

Tretamine

Cause chromatid aberrations<smiles>CC(O)CNc1nc(Cc2ccnc(C(F)(F)F)c2)nc(-c2cccc(C(F)(F)F)n2)n1</smiles>

Isocitrate dehydrogenase inhibitor<smiles>CN(C)C1CCN(C(=O)c2ccc(NC(=O)Nc3ccc(-c4nc(N5CCOCC5)nc(N5CCOCC5)n4)cc3)cc2)CC1</smiles>

Inhibits proliferation and invasion of $\mathrm{Hs} 578 \mathrm{~T}$ triple-negative (TN) breast cancer cells<smiles>CCCc1ccccc1Nc1nc(N)nc(N(C)C)n1</smiles>

HL010183

$$
\begin{aligned}
& \text { Gedatolisib } \\
& \text { Targets PI3K/mTOR }
\end{aligned}
$$<smiles>COc1nc(NCCc2c[nH]c3ccccc23)nc(Nc2ccc3[nH]ncc3c2)n1</smiles>

KY-04031

PAK4 inhibitor

Figure 2. Some commercial drugs bearing the s-triazine ring.

Taking advantage of the unique reactivity shown by TCT, we have synthesized several s-triazine derivatives and evaluated their activity for several biological targets, which will be discussed in subsequent sections [13,14,21-28]. TCT has been further explored as a linker that encompasses two key chemical concepts, namely orthogonality and chemoselectivity $[8,16,29]$. This review compiles all these results on TCT and broadly covers the following three sections: synthetic strategy; biological activity; and orthogonal chemoselectivity.

\section{Synthesis of s-Triazine Derivatives}

Several derivatives were synthesized via different routes, resulting in eight series, as shown in Scheme 1. The replacement of the first and second $\mathrm{Cl}$ atoms was achieved in the presence of a base at $0{ }^{\circ} \mathrm{C}$ and room temperature (rt), respectively. Different nucleophiles like piperidine, morpholine, benzylamine, and methanol $(\mathrm{MeOH})$ were used for the replacement of the first and second $\mathrm{Cl}$ atoms in the presence of bases such as triethylamine (TEA), diisopropylethylamine (DIEA), $\mathrm{Na}_{2} \mathrm{CO}_{3}$, etc. Series 1 was synthesized using dimethoxy-substituted s-triazine [21]. In this series, a solution of dimethoxy-substituted s-triazine and TEA in dioxane was reacted until a white suspension formed. A solution of amino acid and TEA in dioxane- $\mathrm{H}_{2} \mathrm{O}(1: 1)$ was added to form a clear solution. The reaction was stirred overnight at $\mathrm{rt}$ followed by neutralization with $1 \mathrm{~N} \mathrm{HCl}$ to yield a white solid, which afforded the desired products (seven derivatives) upon filtration and drying. In Series 2, a protocol similar to that described above was followed for the second substitution in piperidine/morpholine-substituted using monosubstituted dichlorotriazine (m-DCT). After stirring the reaction overnight at $\mathrm{rt}$, a solution of piperidine/morpholine and TEA was added to replace the third $\mathrm{Cl}$ atom. The reaction mixture was heated at $75-80{ }^{\circ} \mathrm{C}$ for $5 \mathrm{~h}$ and then neutralized with $5 \%$ citric acid/ $1 \mathrm{~N} \mathrm{HCl}$, resulting in precipitation. Filtration and drying afforded the desired products (14 derivatives) [21]. 


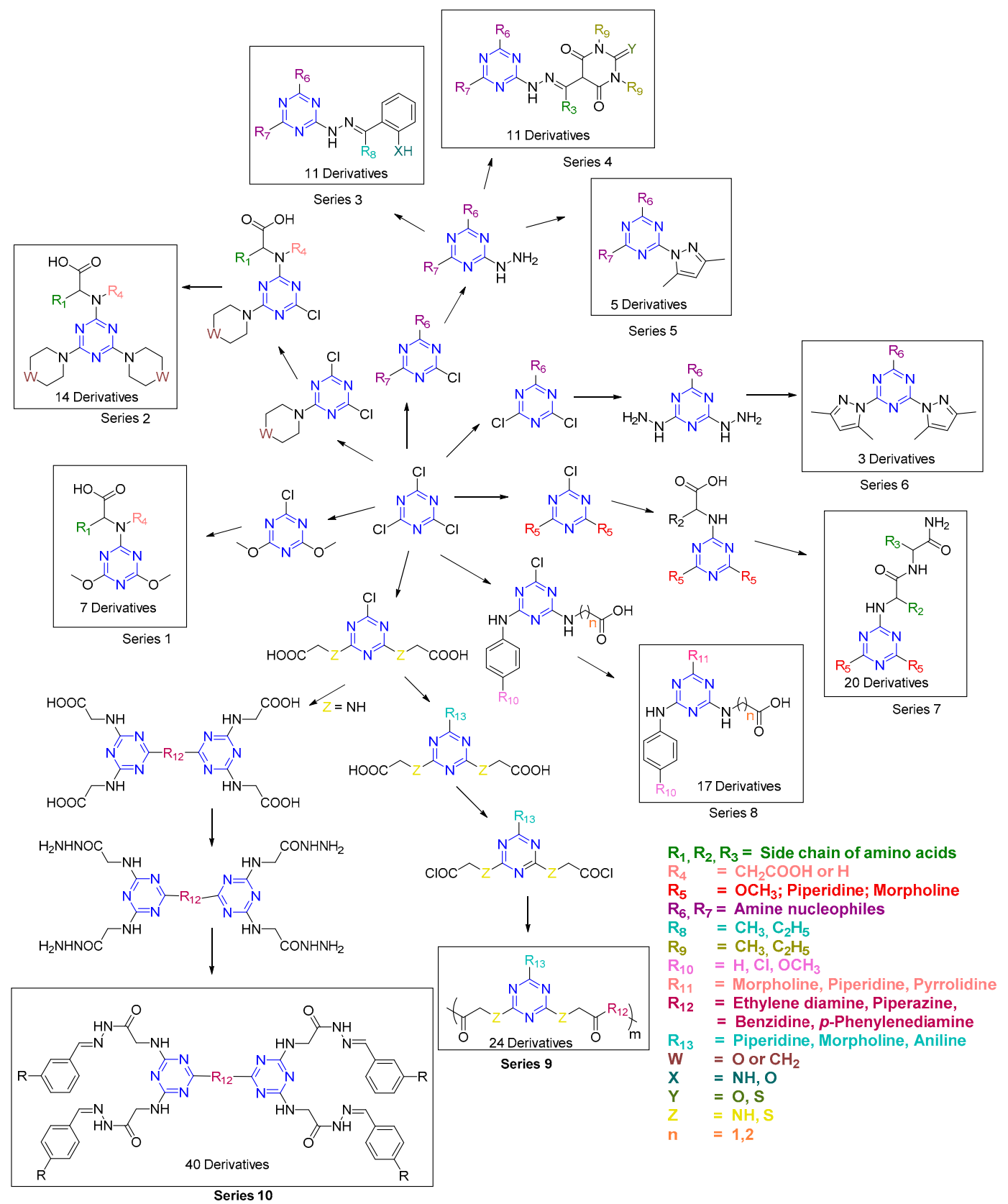

Scheme 1. Scheme for the synthesis of s-triazine derivatives.

Hydrazone derivatives bearing a s-triazine core (Series 3 and 4) were synthesized [13,15,24]. Disubstituted-monochloro triazines (d-MCTs) were synthesized using piperidine and morpholine as nucleophiles. $\mathrm{NaHCO}_{3}$ was used as base. The first $\mathrm{Cl}$ atom replacement was performed at $0{ }^{\circ} \mathrm{C}$ for $2 \mathrm{~h}$ followed by in situ replacement of the second $\mathrm{Cl}$ atom at $\mathrm{rt}$ overnight. The product was precipitated upon removal of the solvent. After filtration and drying, the product was reacted with hydrazine using ethanol as solvent. The reaction was sonicated at $60^{\circ} \mathrm{C}$ for $1 \mathrm{~h}$. Ethanol was removed, and the desired product (hydrazinyl trisubstituted s-triazine) was precipitated using excess diethyl ether. A Schiff base was synthesized using two methods (one method under reflux and the other method in an Erlenmeyer flask). To this end, 2-3 drops of acetic acid, followed by hydrazinyl trisubstituted s-triazine, were added to a solution of 2-substituted acetophenone (for Series 3) or pyrimidinetrione/thiopyrimidinetrione (for Series 4 ) in ethanol. The reaction mixture was refluxed for $3 \mathrm{~h}$ (in the other case, at $40^{\circ} \mathrm{C}$ for $1 \mathrm{~h}$ ). In both cases, after reaction, ethanol 
was removed, resulting in precipitation. The reaction mixture was then filtered and dried. Recrystallization (ethyl acetate or ethanol) afforded the desired products (Series 3 and 4).

Pyrazole derivatives (Series 5 and 6) were synthesized by Method A and Method B [14]. Initially, m-DCTs and d-MCTs derivatives bearing piperidine, morpholine, or benzyl amine were prepared as per the procedure explained above. m-DCTs/d-MCTs were reacted with hydrazine hydrate to afford di/mono-hydrazinyl trisubstituted s-triazine. In Method A, this compound was dissolved in DMF and acetylacetone was then added. TEA was added and the reaction was refluxed for $6-8 \mathrm{~h}$. Ice-cooled $\mathrm{H}_{2} \mathrm{O}$ was added to precipitate the desired products, which were obtained by filtration, drying, and recrystallizing using ethanol (Series 5 and 6). In Method B, acetylacetone was added dropwise to a solution of mono/di-hydrazinyl trisubstituted s-triazine in $\mathrm{HClO}_{4}$. The reaction was stirred at rt overnight. The reaction mixture was neutralized with $\mathrm{K}_{2} \mathrm{CO}_{3}$ to form a precipitate. Filtration and drying afforded the desired products (Series 5 and 6) as above. Method B afforded better yields than Method A.

Amino acid derivatives of s-triazine (Series 7) were prepared as explained for Series 1 [22]. 1-[Bis(dimethylamino)methylene]-1H-1,2,3-triazolo[4,5-b]pyridinium 3-oxide hexafluorophosphate (HATU) was used as coupling reagent in the presence of DIEA as base. A solution of amino acid ester in DIEA and DMF was added to the stirring solution of the amino acid derivative of triazine. The reaction was stirred overnight at $\mathrm{rt}$. The reaction mixture was diluted with ethyl acetate and extracted using 5\% citric acid, sat. $\mathrm{NaHCO}_{3}$, and sat. $\mathrm{NaCl}$. The organic compound was collected, dried using $\mathrm{MgSO}_{4}$, filtered, and concentrated to afford the desired products (Series 7).

Disubstituted s-triazine derivatives (Series 8) were synthesized as explained earlier using amino acids/substituted anilines and aq. $\mathrm{NaHCO}_{3}$ as base (first $\mathrm{Cl}$ atom replacement at $0{ }^{\circ} \mathrm{C}$ for $2 \mathrm{~h}$ and second $\mathrm{Cl}$ atom at rt overnight). The third nucleophile (morpholine, piperidine, and pyrrolidine) was reacted with disubstituted s-triazine in the presence of DIEA as base and THF as solvent using three approaches, namely conventional heating (reflux 20-24 h), microwave (12-15 min at $70{ }^{\circ} \mathrm{C}$ ), and ultrasonication $(1.5 \mathrm{~h} \mathrm{at} \mathrm{rt}$ ). A total of 17 derivatives were synthesized using all three approaches (Series 8). The last two approaches outperformed conventional heating in terms of yield and purity [30].

Diamino acid derivatives of s-triazine were prepared as explained above using TCT and two equiv. of glycine/thioglycolic acid with $\mathrm{Na}_{2} \mathrm{CO}_{3}$ as base and acetone- $\mathrm{H}_{2} \mathrm{O}$ as solvent. The reaction was stirred at $\mathrm{rt}$ for $24 \mathrm{~h}$ to afford the desired products $[27,28]$, which were further reacted with different amines (piperidine, morpholine, or aniline) in the presence of $\mathrm{Na}_{2} \mathrm{CO}_{3}$ as base in dioxane and under reflux conditions for $24 \mathrm{~h}$. The product was then reacted with thionyl chloride to regenerate the diacid chloride, which was then reacted with diamine (ethylene diamine, benzidine, piperazine, or $p$-phenylenediamine) in TEA and DMF to afford the desired polyamides (Series 9, Scheme 1) [27].

The diamino acid derivatives were further reacted with diamine as mentioned above in dioxane- $\mathrm{H}_{2} \mathrm{O}$ as solvent and $\mathrm{Na}_{2} \mathrm{CO}_{3}$ as base under reflux for $24 \mathrm{~h}$ to afford tetracarboxylic acid derivatives. The hydrazide derivatives were synthesized by reacting the tetracarboxylic acid derivatives with $\mathrm{MeOH}$ in the presence of $\mathrm{H}_{2} \mathrm{SO}_{4}$ as catalyst, followed by a reaction with hydrazine hydrate. Upon the reaction with different aldehydes in dioxane- $\mathrm{H}_{2} \mathrm{O}$ (reflux $3 \mathrm{~h}$ ), these derivatives afforded the desired Schiff base derivatives (Series 10, Scheme 1).

\section{Biological Evaluation}

\subsection{MAO-A and $-B$ Inhibitors}

The biological activity of all the synthesized derivatives was evaluated. Series 1 and 2 were examined as inhibitors of monoamine oxidase A and B (MAO-A and - B). Of the 21 derivatives synthesized, the inhibitory effect of three was comparable to the reference compound clorgyline, and they showed greater selectivity toward MAO-A than MAO-B and with no significant toxicity (Figure 3) [21]. 
<smiles>COc1nc(NC(Cc2ccccc2)C(=O)O)nc(OC)n1</smiles><smiles>CC(C)C(Nc1nc(N2CCCCC2)nc(N2CCCCC2)n1)C(=O)O</smiles><smiles>CC(C)C(Nc1nc(N2CCOCC2)nc(N2CCOCC2)n1)C(=O)O</smiles>

Figure 3. Potential compounds as inhibitors of monoamine oxidase A and B (MAO-A and B).

\subsection{Antiproliferative/Anticancer Activity}

Series 3 and 4 (Schiff base analogs) [13,24] and Series 6 (Pyrazole) [23] were evaluated for anticancer activity against Lung carcinoma (A549), Hepatocellular carcinoma (HepG2), Adenocarcinoma (MCF-7), Human breast cancer (MCF, MDA-MB-231), Human colorectal carcinoma (LoVo, HCT-116), and Human leukemia (K562). Out of all the 34 derivatives, Figure 4 shows the derivatives possessing Schiff base analogs, which showed higher antiproliferative/anticancer activity than pyrazole derivatives (Figure 4). The presence of two pyrazoles on the s-triazine core had a negative impact on bioactivity. Of the Schiff base derivatives, pyrimidinetrione/thiopyrimidinetrione appeared to be the best choice for A549 and HepG2 cell lines. s-Triazine bearing thiopyrimidinetrione with piperidine enhanced the activity compared to morpholine $[13,23,24]$.<smiles>COc1nc(N/N=C(\C)c2ccccc2O)nc(N/N=C(\C)c2ccccc2O)n1</smiles>
HepG2 = $15.5( \pm 1.7)$<smiles>Cc1cc(C)n(-c2nc(N3CCCCC3)nc(-n3nc(C)cc3C)n2)n1</smiles>

$\mathrm{MCF}=7.5$ MDA-MB-231 $=14$ HepG2 $=17.5$ LoVo $=6.1$ $\mathrm{K} 562=9.8$
A549 = $5.6( \pm 1.1)$ HepG2 = $6.5( \pm 1.7)$<smiles>Cc1cc(C)n(-c2nc(N3CCCCC3)nc(N3CCCCC3)n2)n1</smiles>

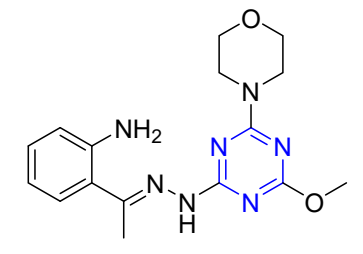

A549 $=9.3( \pm 1.6)$ HepG2 $=1.5( \pm 0.25)$<smiles>CCN(CC)c1nc(N/N=C(\C)C2C(=O)N(C)C(=S)N(C)C2=O)nc(N2CCOCC2)n1</smiles>

A549 $=9.7( \pm 3.3)$

HepG2 $=11.0( \pm 0.2)$

HCT-116 $=7.9( \pm 0.3)$

MCF-7 $=15.8( \pm 0.7)$

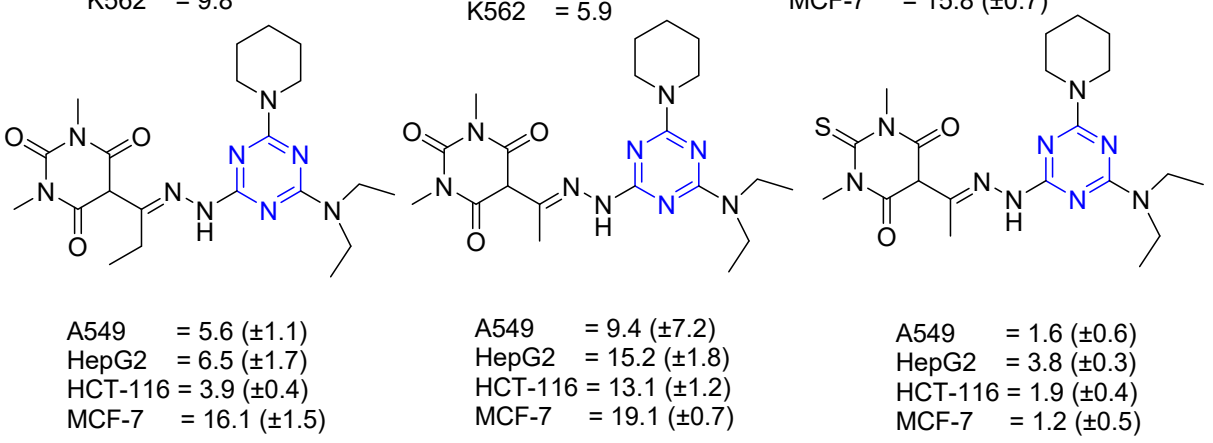

Figure 4. Compounds showing antiproliferative/anticancer activity $\left(\mathrm{IC}_{50}\right)$.

\subsection{Antimicrobial Activity}

Pyrazole derivatives (Series 5 and 6) and substituted aniline derivatives (Series 8) were evaluated for antimicrobial activity (measured as zone of inhibition in $\mathrm{mm}$ ) [14,30]. 
Figure 5 shows the structures of all the active analogs. The activity of the derivatives against cultures of Gram-negative bacteria (E. coli ATCC 25922, P. aeruginosa ATCC 75853, S. typhimurium ATCC 14028), Gram-positive bacteria (M. luteus ATCC 10240, Methicillinresistant Staphylococcus aureus (MRSA) ATCC 43300, S. epidermidis ATCC 12228), and C. albicans ATCC 10145 and 60193 (fungi) was tested. Two pyrazole rings incorporated in the s-triazine ring are detrimental to the antimicrobial activity compared to one ring. Of all the derivatives, s-triazine with pyrazole, benzylamine, and piperidine have been found to be most active. The presence of the morpholine ring along with the secondary amine is relevant for antifungal activity [14]. The presence of piperidine in Series 8 appeared to be important for antifungal activity. Electron-withdrawing groups like $\mathrm{Cl}$ enhanced antifungal activity compared to their methoxy counterparts [30].

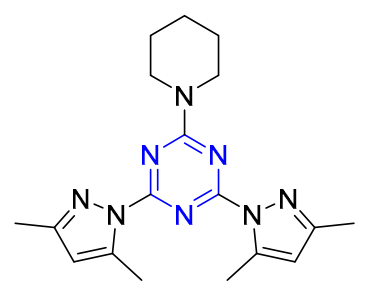

$P$. aeruginosa $=13$

$M$. luteus $=17$

MRSA $=11$<smiles>Cc1cc(C)n(-c2nc(NCc3ccccc3)nc(N3CCCCC3)n2)n1</smiles>

$P$. aeruginosa $=19$

$M$. luteus $=22$

MRSA

$=11$

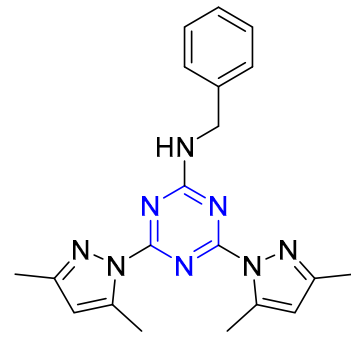

$P$. aeruginosa $=13$

$M$. luteus $=15$

MRSA $=7$<smiles>CCN(CC)c1nc(N2CCOCC2)nc(-n2nc(C)cc2C)n1</smiles>

$P$. aeruginosa $=9$

M. luteus $=17$

MRSA $=8$

C. albicans $=8$<smiles>Cc1cc(C)n(-c2nc(NCc3ccccc3)nc(N3CCOCC3)n2)n1</smiles>

$P$. aeruginosa $=17$

$M$. luteus $=9$

MRSA<smiles>Cc1cc(C)n(-c2nc(N3CCCCC3)nc(N3CCOCC3)n2)n1</smiles>

C. albicans $=9$<smiles>O=C(O)CNc1nc(Nc2ccccc2)nc(N2CCCCC2)n1</smiles><smiles>Nc1ccc(Cl)cc1</smiles><smiles>C1CCNCC1</smiles><smiles>C1CC1</smiles><smiles>COc1ccc(Nc2nc(NCC(=O)O)nc(N3CCCCC3)n2)cc1</smiles>

C. albicans $=15 \pm 0.2(50 \mu \mathrm{g})$

C. albicans $=13 \pm 0.1(50 \mu \mathrm{g})$

C. albicans $=14 \pm 0.4(50 \mu \mathrm{g})$

Figure 5. Compounds with antimicrobial activity (as zone of inhibition in $\mathrm{mm}$ ).

Dimeric s-triazine hydrazide and its Schiff base derivatives (Series 9) were screened in vitro for antimicrobial activity against S. aureus (ATCC 19433), E. coli (ATCC 25922), and C. albicans as a yeast-like fungus [28]. The derivatives showed good antibacterial activity (Figure 6) but no antifungal activity. The active compounds were further screened for antibacterial activity against multidrug-resistant (MDR) clinical isolates. The results showed a promising inhibition efficiency, comparable to the standard drug ampicillin trihydrate. The active compounds also showed a high selectivity index toward antimicrobial activity compared to mammalian cells, with a good safety profile. Electron-withdrawing groups were crucial for enhancing antibacterial activity [28]. Moreover, an aliphatic core appeared to have a detrimental effect on the activity compared to an aromatic core [28]. 


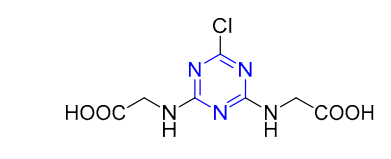

K. pneumonia $=12.5 \mu \mathrm{g} / \mathrm{mL} ; \mathrm{SI}=40 \mu \mathrm{g} / \mathrm{mL}$ MRSA1 $=3.125 \mu \mathrm{g} / \mathrm{mL} ; \mathrm{SI}=160 \mu \mathrm{g} / \mathrm{mL}$
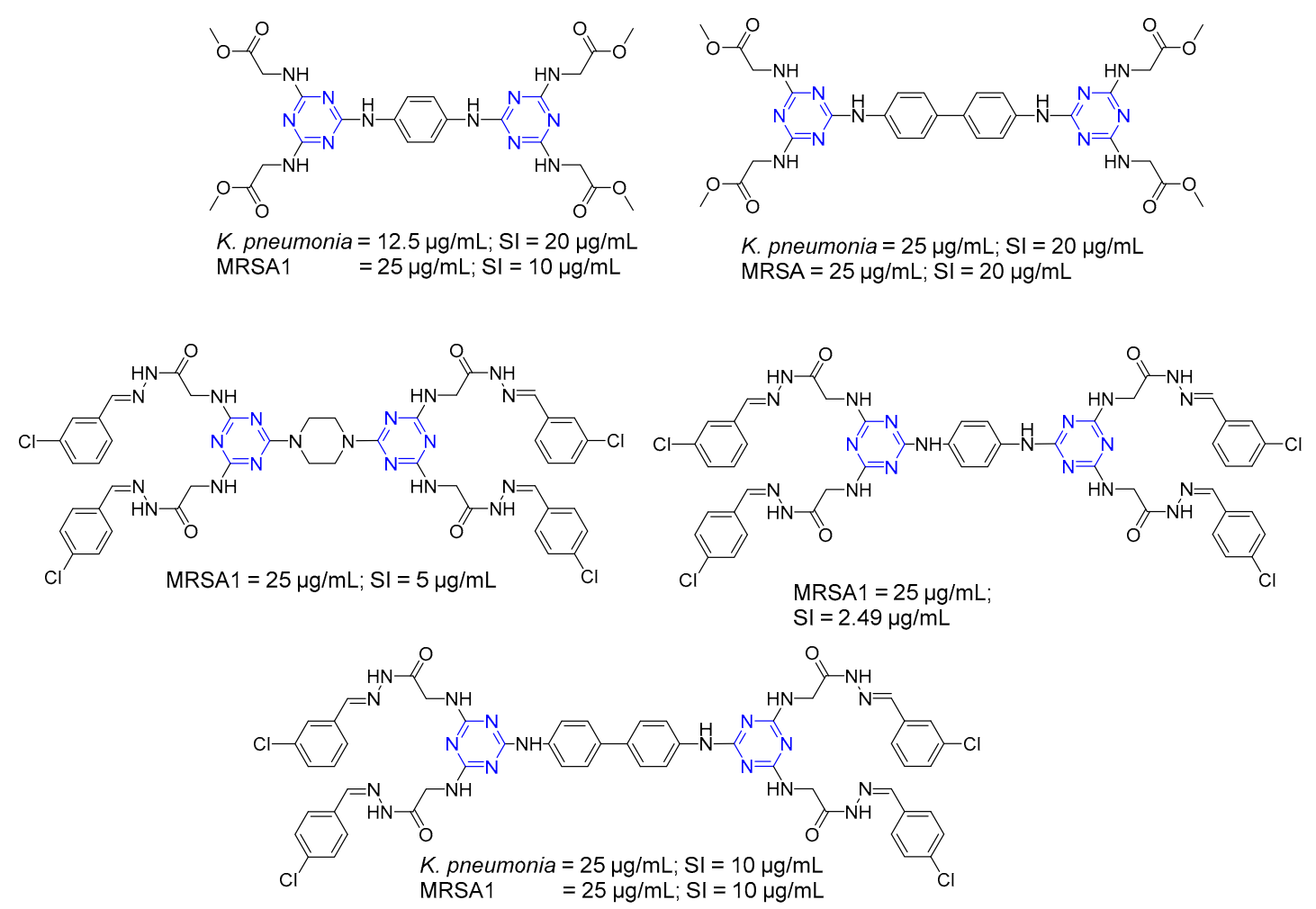

Figure 6. Minimum Inhibitory Concentration (MIC) and selectivity index (SI) of compounds showing activity against $K$. pneumonia and MRSA1.

The feasibility of s-triazine polyamides containing Gly and thioglycolic acid (Series 10) as drug nano delivery systems was examined. The nanoparticles (NPs) were loaded with celecoxib (CXB), an anti-inflammatory drug with a promising anti-cancer effect. The NPs showed high entrapment efficiency levels (62.3-99.8\%) with drug loading between $1.58 \%$ and $4.19 \%$. After $48 \mathrm{~h}, 46.90,64.20,57.81,53.95$, and $49.43 \%$ of CXB were released from polymeric NPs $26,43,44,45$, and 46 , respectively, thereby demonstrating a sustained drug release profile. Notably, free CXB and CXB-loaded polymeric NPs CXB-43, CXB-45, and CXB-46 caused a considerable reduction in cell viability in a dose-dependent manner. Moreover, NPs were cytotoxic against breast cancer cells (MCF-7). Overall, these NPs hold great promise as drug delivery systems and are expected to accumulate significantly in tumor tissues via the EPR effect, thereby maximizing the antitumor efficacy of drugs and reducing systemic toxicity [27].

\subsection{Antileishmanial Activity}

Series 7 (20 derivatives) comprising the hybrid molecules of the 1,3,5-triazine moiety and short hydrophobic peptides were evaluated against L. aethiopica using miltefosine and amphotericin B as reference drugs [22]. The in vitro anti-promastigote activity of all the derivatives was studied. Four compounds were found to be active. The dimethoxy derivatives were more active than the corresponding dipiperidine and dimorpholine derivatives. The derivative with Gly-Val dipeptide was five times more active than miltefosine. These four derivatives were further tested for in vitro anti-amastigote and cytotoxicity followed 
by in vivo anti-toxicity (Figure 7). The compounds showed low toxicity. A combination of cytotoxicity and antileishmanial activities showed greater selectivity toward the protozoa (L. aethiopica) than mammalian cells, indicating a safe toxicity profile.

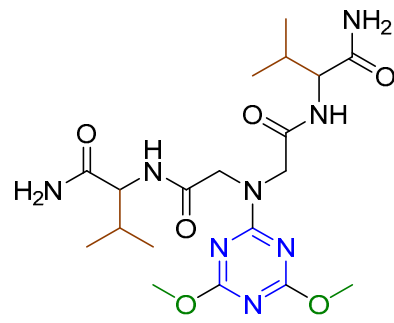

$1.4 \pm 0.04(0.02 \pm 0.02)$

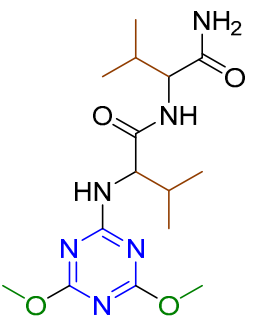

$4.7 \pm 0.11(0.47 \pm 0.08)$

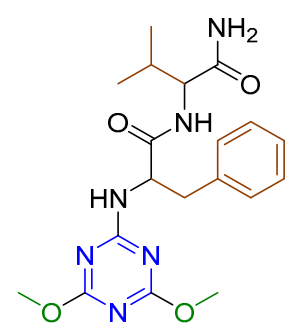

$2.3 \pm 0.06(0.37 \pm 0.06)$

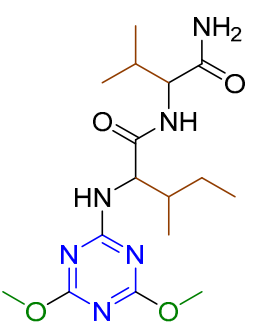

$5.0 \pm 0.08(0.55 \pm 0.08)$

Figure 7. Compounds active against antileishmanial activity. The values are measured as $\mathrm{IC}_{50}$ in $\mu \mathrm{M}$ for anti-promastigote (anti-amastigote) activity.

\section{Orthogonal Chemoselectivity}

The uniqueness of TCT undergoing a sequential nucleophilic substitution reaction has been exploited to explain orthogonal chemoselectivity. Orthogonality and chemoselectivity are two interchangeable words widely used in bioconjugation, although the former is a subset of the latter. Orthogonality was first introduced by Barany and Merrifield in 1977 [31] and demonstrated by Barany and Albericio in 1985 as "Orthogonal protecting groups", which can be successfully removed in any order by various chemical mechanisms and in the presence of other protecting groups [32]. At the same time and in parallel, in 1983, Trost coined the term "Chemoselectivity" to describe the ability of a chemical reagent to discriminate among reactive sites [33]. The fusion of these two concepts, "Orthogonal Chemoselectivity", was defined by our group as a "discrimination between reactive sites in any order" [8].

\subsection{Reactivity of TCT with Nucleophiles}

The concept of Orthogonal Chemoselectivity using TCT as the core linker using amine $(\mathrm{NH})$, thiol $(\mathrm{SH})$, and alcohol/phenol $(\mathrm{OH} / \mathrm{pOH})$ as nucleophiles (mimicking amino acid side chains present in proteins) has been demonstrated [8,9]. Scheme 2 shows the series of reactions attempted to explain the order of incorporation.

TCT was reacted in parallel with $\mathrm{NH}, \mathrm{SH}$, and $\mathrm{OH}$ in the presence of DIEA at $0{ }^{\circ} \mathrm{C}$ to form m-DCTs. Since all the reactions to form m-DCTs (TCT-NH, TCT-OH, and TCT-SH) proceeded at the same rate, a competitive test was conducted to determine the selectivity of TCT in the presence of all the three nucleophiles at $0{ }^{\circ} \mathrm{C}$ for $30 \mathrm{~min}$ in a one-pot reaction (Figure 8). It was observed that $\mathrm{NH}$ is prevalent over $\mathrm{SH}$ and $\mathrm{OH}$ when present in the same reaction mixture, thereby indicating a high selectivity of the former. For the replacement of the second $\mathrm{Cl}$ atom, another equivalent of nucleophile was added in the presence of DIEA at rt overnight $(12 \mathrm{~h})$. Our results indicate that once $\mathrm{NH}$ is introduced, only another amine can be incorporated as either $\mathrm{SH}$ or $\mathrm{OH}$, and cannot be incorporated further in m-DCTs under the same reaction conditions. The replacement of the third $\mathrm{Cl}$ atom was performed at $75{ }^{\circ} \mathrm{C}$ overnight. Of all the reactions attempted, the preferential order of incorporation was found to be first $\mathrm{OH}$, then $\mathrm{SH}$, and finally $\mathrm{NH}$. However, the last replacement was still performed at a temperature incompatible with the application in peptides/proteins. Therefore, $\mathrm{OH}$ was replaced by phenol (pOH), as shown in Scheme 1 [9]. The first incorporation of $\mathrm{pOH}$ was achieved at $-20{ }^{\circ} \mathrm{C}$ instead of $0{ }^{\circ} \mathrm{C}$ due to the high nucleophilicity of $\mathrm{pOH}$. The presence of pOH also allowed the replacement of the third $\mathrm{Cl}$ atom by $\mathrm{NH}$ in $8 \mathrm{~h}$ at $35^{\circ} \mathrm{C}$ (temperature compatible with applications using peptide/proteins). 

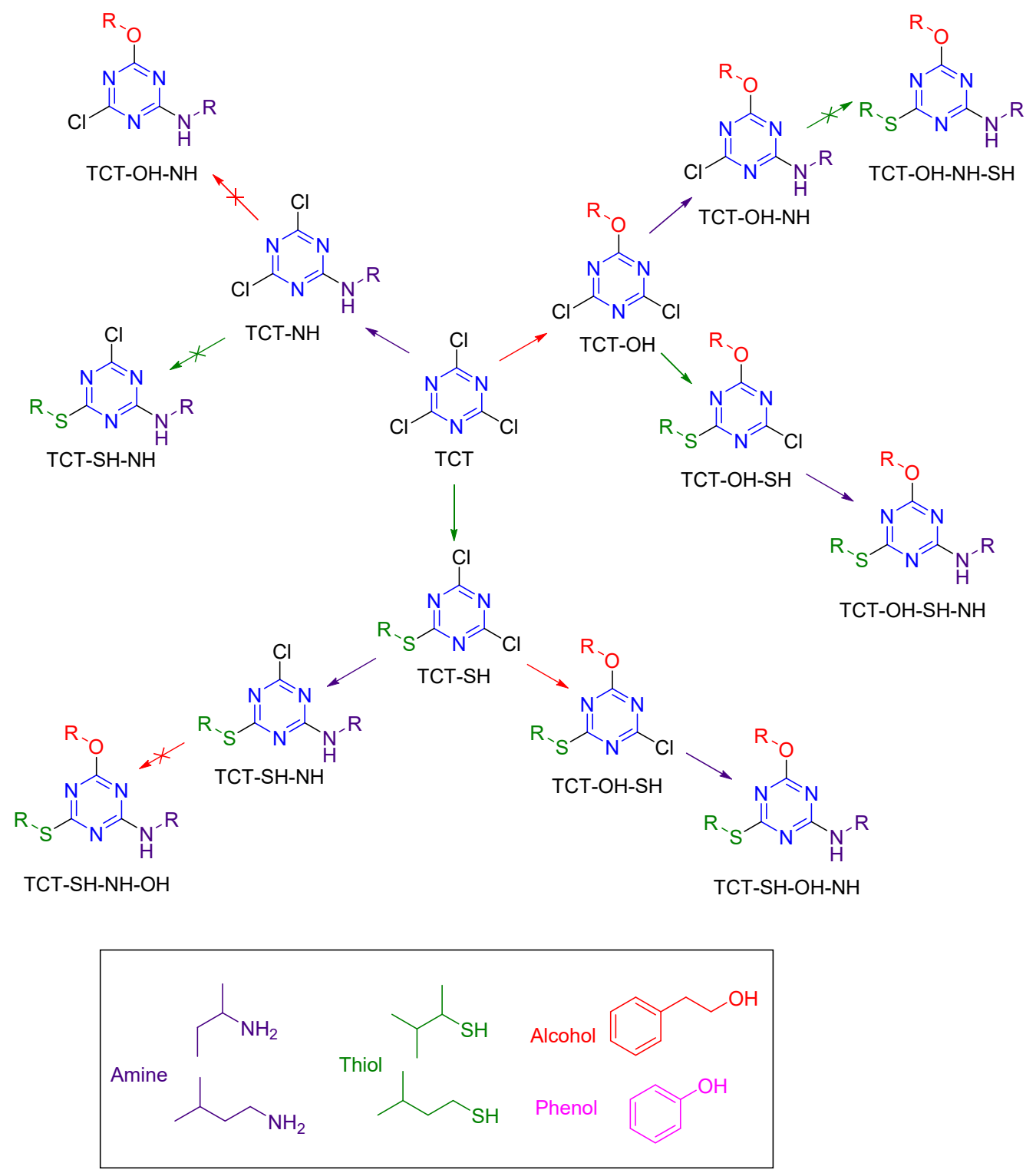

Scheme 2. Reactions attempted on TCT with nucleophiles $(\mathrm{NH}, \mathrm{SH}$, and $\mathrm{OH} / \mathrm{pOH})$ and the preferential order of incorporation was found to be first alcohol/phenol, second thiol, and third amine.<smiles>[R]Nc1nc(Cl)nc(Cl)n1</smiles>

Figure 8. Competitive reaction of TCT with all nucleophiles in one pot.

With the advantage of $\mathrm{pOH}$ in modulating the reaction of the s-triazine core, a $1+2$ mode (one nucleophile as the first substitution followed by another nucleophile for the other two positions) as an application for dendrimer synthesis was also attempted (Scheme 3). 


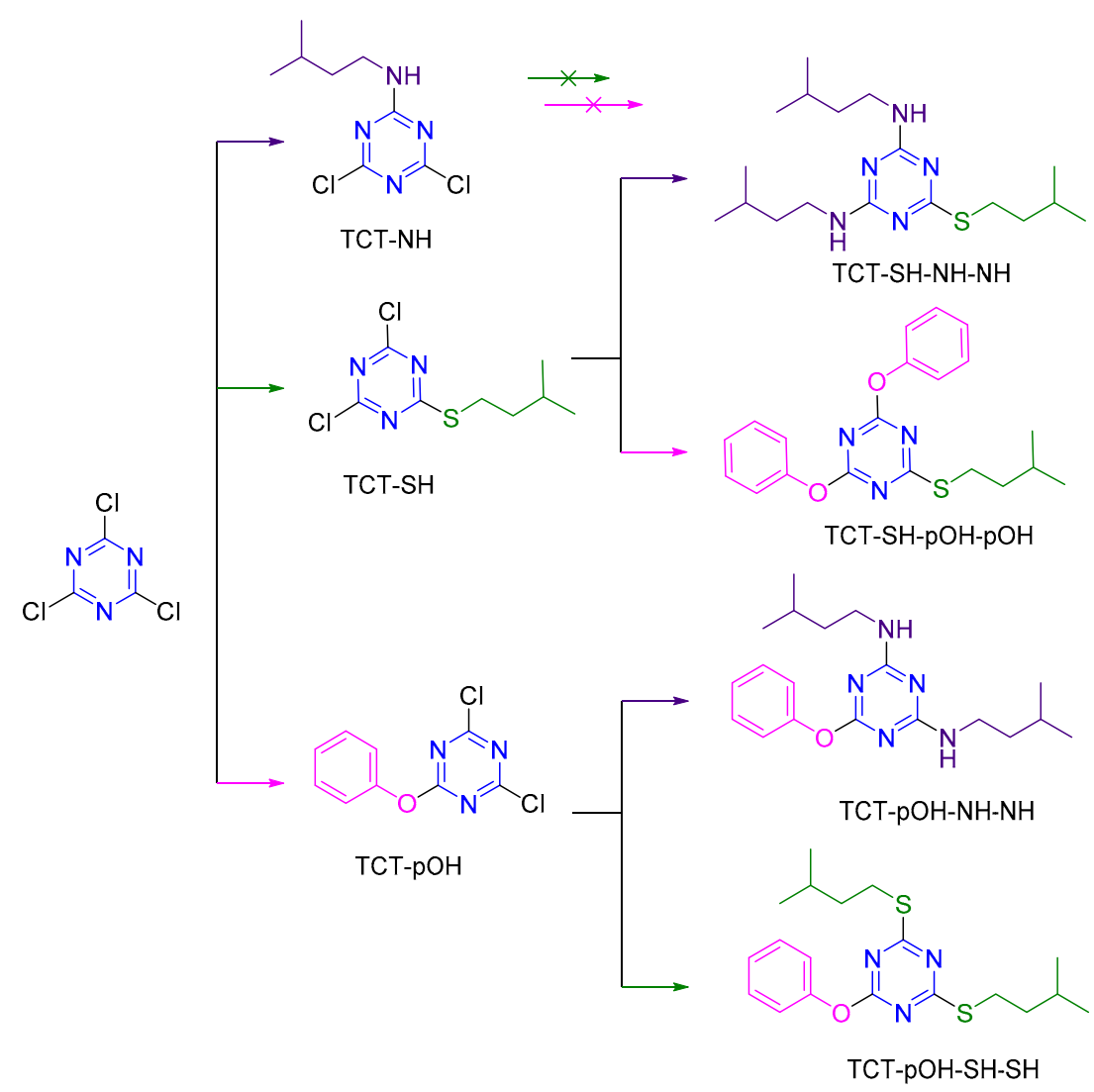

Scheme 3. Reactions for the $1+2$ mode between TCT and nucleophiles $(\mathrm{NH}, \mathrm{SH}$, and $\mathrm{pOH})$.

$\mathrm{m}$-DCTs were prepared as explained above, followed by the addition of 2 eq. of each nucleophile in the presence of DIEA. The reaction was stirred at $35^{\circ} \mathrm{C}$ for $12 \mathrm{~h}$. As depicted in Scheme 3, TCT-NH did not react with $\mathrm{SH}$ or $\mathrm{pOH}$. These results are consistent with our earlier findings. For the rest, TCT-SH and TCT-pOH form the respective products, affording TCT-SH-(NH $)_{2} /$ TCT-SH-(pOH $)_{2}$ and TCT-pOH-(NH $)_{2} /$ TCT-pOH-(SH $)_{2}$, respectively. However, since the reactivity of TCT for the last $\mathrm{Cl}$ atom substitution reaction depends upon the order of nucleophile incorporation, its use as a linker is limited.

\subsection{Tri-orthogonal Chemoselectivity with Azide as Modifier}

The concept of Orthogonal Chemoselectivity using TCT as the core linker and amine $(\mathrm{NH})$, thiol $(\mathrm{SH})$, and alcohol/phenol $(\mathrm{OH} / \mathrm{pOH})$ as nucleophiles (mimicking amino acid side chains present in proteins) has been demonstrated [8,9]. Scheme 2 shows the series of reactions attempted to explain the order of incorporation.

Any electron-withdrawing group tends to maintain the electron density in TCT reactivity. In this regard, azide was used as a modifier. Tri-orthogonal chemoselectivity was explained using the TCT core and the above-mentioned nucleophiles with $\mathrm{N}_{3}$ as a modifier. The presence of $\mathrm{N}_{3}$ in TCT was studied in all three positions (Scheme 4). TCT- $\mathrm{N}_{3}$ contains $\mathrm{N}_{3}$ in the first position. Few studies have addressed TCT- $\mathrm{N}_{3}$ [34-36]. The high reactivity of $\mathrm{N}_{3}$ makes it difficult to control the reaction selectively for the first position. Furthermore, due to the explosive nature of TCT- $\mathrm{N}_{3}$, scaling up and purification makes the process cumbersome. We have developed a safe method with high selectivity for the first position [16]. During the synthesis, an equimolar solution of $\mathrm{NaN}_{3}$ was added dropwise into a TCT solution in acetone. After $30 \mathrm{~min}$, acetone was removed at $0{ }^{\circ} \mathrm{C}$ (to avoid unreacted $\mathrm{NaN}_{3}$ for further reaction). The aqueous solution was extracted using cold DCM (to avoid explosion in a bigger reaction scale due to generation of heat in the separatory funnel) and concentrated to obtain the crude product, which was purified using $n$-hexane in an isocratic silica gel column, to achieve an overall yield of $90.4 \%(4.7 \mathrm{~g})$ [16]. 


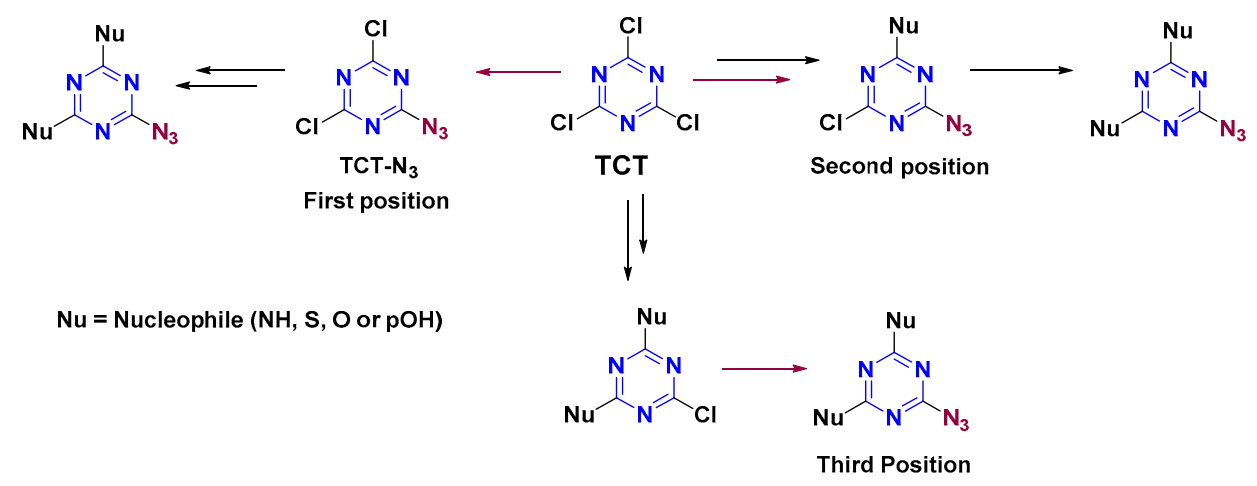

Scheme 4. General scheme showing azide as modifier in all the three positions in TCT.

Once TCT- $\mathrm{N}_{3}$ had been synthesized, the second $\mathrm{Cl}$ atom was replaced using $\mathrm{NH}, \mathrm{SH}$, and $\mathrm{OH} / \mathrm{pOH}$ (Scheme 5). The reaction was completed in $30 \mathrm{~min}$ at $0{ }^{\circ} \mathrm{C}$ in the case of $\mathrm{NH}$ and $\mathrm{SH}$, and at $-20^{\circ} \mathrm{C}$ for $\mathrm{pOH}$, yielding TCT- $\mathrm{N}_{3}-\mathrm{NH}$, TCT- $\mathrm{N}_{3}-\mathrm{SH}$, and TCT- $\mathrm{N}_{3}-\mathrm{pOH}$, respectively. In the case of TCT- $\mathrm{N}_{3}-\mathrm{NH}$, only another $\mathrm{NH}$ can be used to form TCT- $\mathrm{N}_{3}-$ $\mathrm{NH}-\mathrm{NH}$. The reaction was carried out at $\mathrm{rt}$ for $12 \mathrm{~h}$. Regarding TCT- $\mathrm{N}_{3}-\mathrm{SH} / \mathrm{pOH}$, all the nucleophiles, except for $\mathrm{OH}$, replaced the third $\mathrm{Cl}$ atom in the s-triazine ring. Given these observations, it was inferred that once $\mathrm{N}_{3}$ is present on $\mathrm{TCT}, \mathrm{OH}$ cannot enter any position.

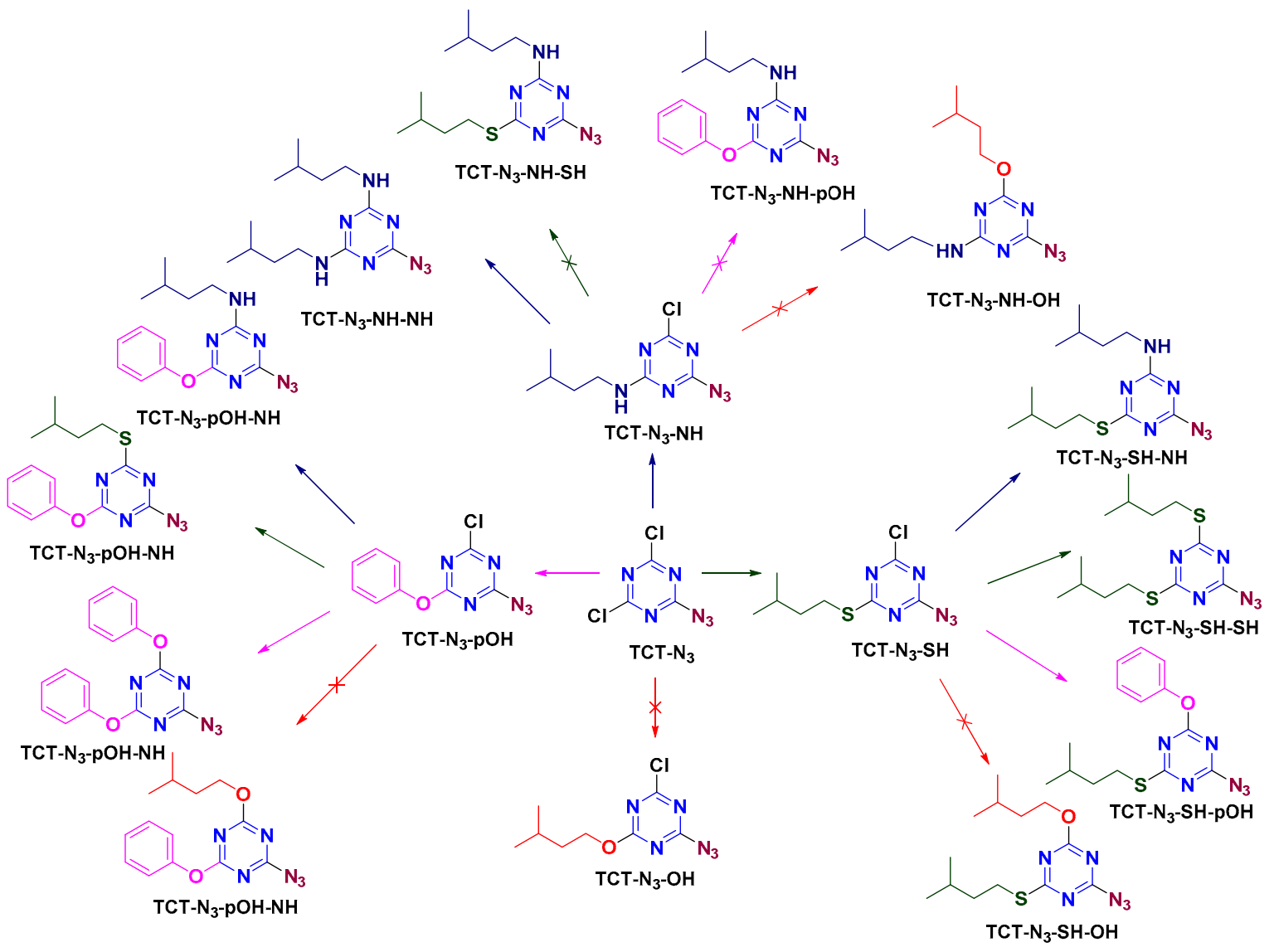

Scheme 5. Azide as modifier in the first position on TCT.

Once $\mathrm{N}_{3}$ had been analyzed at the first position, its effect was evaluated in the second position (Scheme 6). m-DCTs were synthesized as explained above using $\mathrm{NH}, \mathrm{SH}$, and $\mathrm{OH} / \mathrm{pOH}$. Sodium azide $\left(\mathrm{NaN}_{3}\right)$ was reacted with m-DCTs at $0{ }^{\circ} \mathrm{C}$ for $30 \mathrm{~min}$ in the presence of DIEA to afford d-MCTs (TCT-NH-N 3 , TCT-SH-N 3 , and TCT-OH/pOH-N ${ }_{3}$ ). 
TCT-OH- $\mathrm{N}_{3}$ synthesis was successful in this case, as $\mathrm{N}_{3}$ entered the s-triazine ring after $\mathrm{OH}$ had been incorporated (unlike the previous case). $\mathrm{d}-\mathrm{MCTs}$ were then reacted with the above-mentioned nucleophiles at $\mathrm{rt}$ for $12 \mathrm{~h}$. TCT-NH-N 3 afforded only TCT-NH-N $3-\mathrm{NH}$, as once an amine entered no other nucleophile other than another amine can react. TCTSH-N ${ }_{3}$, TCT-OH-N ${ }_{3}$, and TCT-pOH-N ${ }_{3}$ afforded the respective trisubstituted s-triazine in a similar way (TCT-SH-N $3-\mathrm{NH}$, TCT-SH-N ${ }_{3}-\mathrm{SH}, \mathrm{TCT}-\mathrm{SH}-\mathrm{N}_{3}-\mathrm{pOH}, \mathrm{TCT}-\mathrm{OH}-\mathrm{N}_{3}-\mathrm{NH}$, TCT$\mathrm{OH}-\mathrm{N}_{3}-\mathrm{SH}$, TCT-OH-N - - $\mathrm{pOH}$, TCT-pOH-N $3-\mathrm{NH}$, TCT-pOH-N ${ }_{3}-\mathrm{SH}$, TCT-pOH-N $3-\mathrm{pOH}$ ), except in the case of $\mathrm{OH}$ (as once $\mathrm{N}_{3}$ was incorporated in TCT, OH did not react).

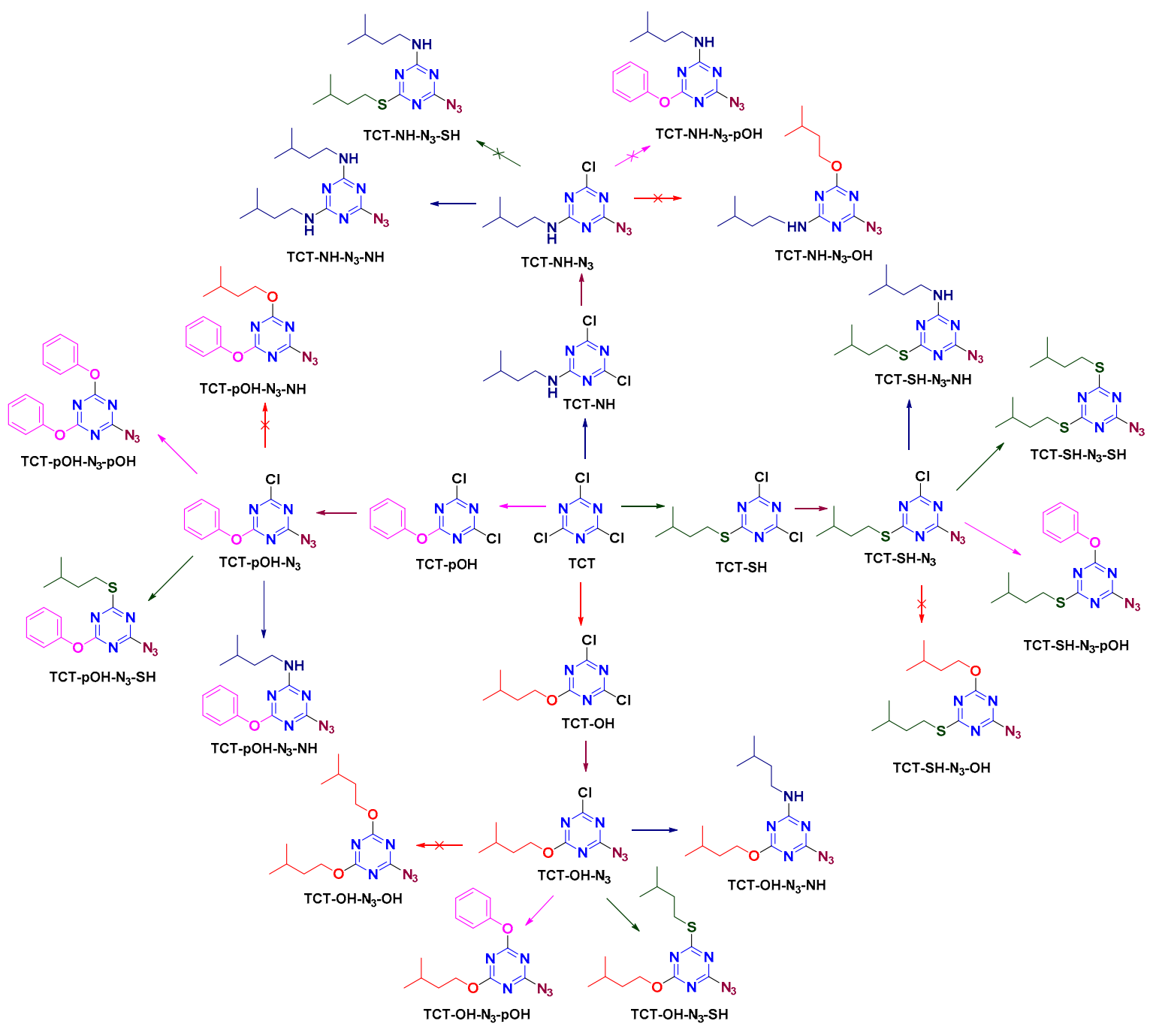

Scheme 6. Azide as modifier in the second position on TCT.

The reactivity of $\mathrm{N}_{3}$ was then studied at the third position (Scheme 7). d-MCTs, where two substituents were either of the above-mentioned nucleophiles $(\mathrm{NH}, \mathrm{SH}, \mathrm{OH}$, and $\mathrm{pOH}$ ), were reacted with $\mathrm{NaN}_{3}$ at $40{ }^{\circ} \mathrm{C}$ for $12 \mathrm{~h}$. The incorporation of $\mathrm{N}_{3}$ was observed in all cases, except when $\mathrm{OH}$ was present and in the case of d-MCTs with two $\mathrm{NH}$.

With the overall idea that $\mathrm{N}_{3}$ in the first position was successful, we further explored its reactivity with peptides bearing $\mathrm{NH}, \mathrm{SH}$, and $\mathrm{pOH}$. In this regard, pentapeptides (AcXaa-Gly-Gly-Phe-Leu- $\mathrm{NH}_{2}$ where Xaa $=$ Lys/Cys/Tyr) were sequentially incorporated into TCT- $\mathrm{N}_{3}$ as shown in Scheme 8. Ser peptide (Ac-Ser-Gly-Gly-Phe-Leu- $\mathrm{NH}_{2}$ ) was eliminated due to the poor nucleophilicity of the alcohol of Ser. 


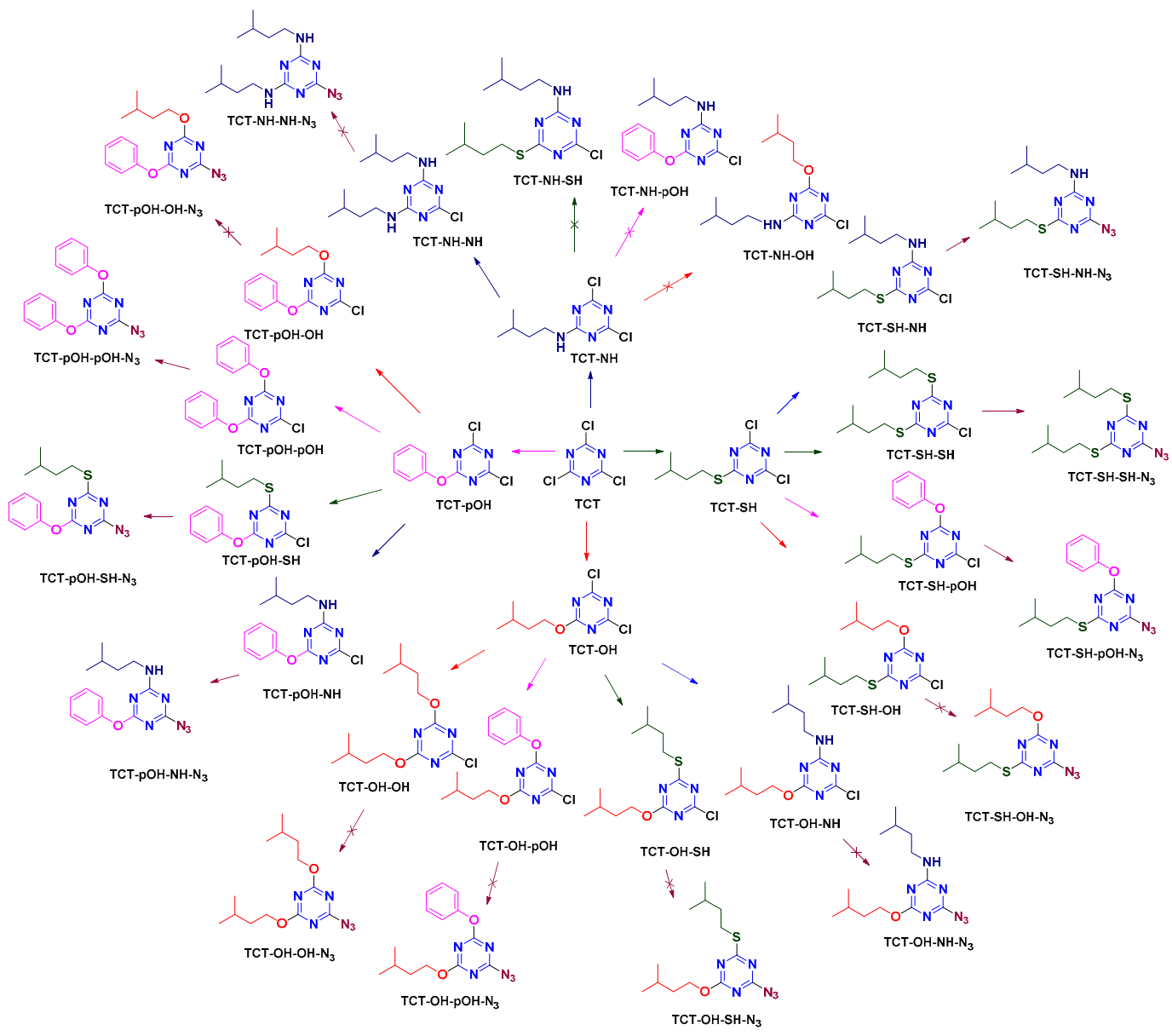

Scheme 7. Azide as modifier in the third position on TCT.

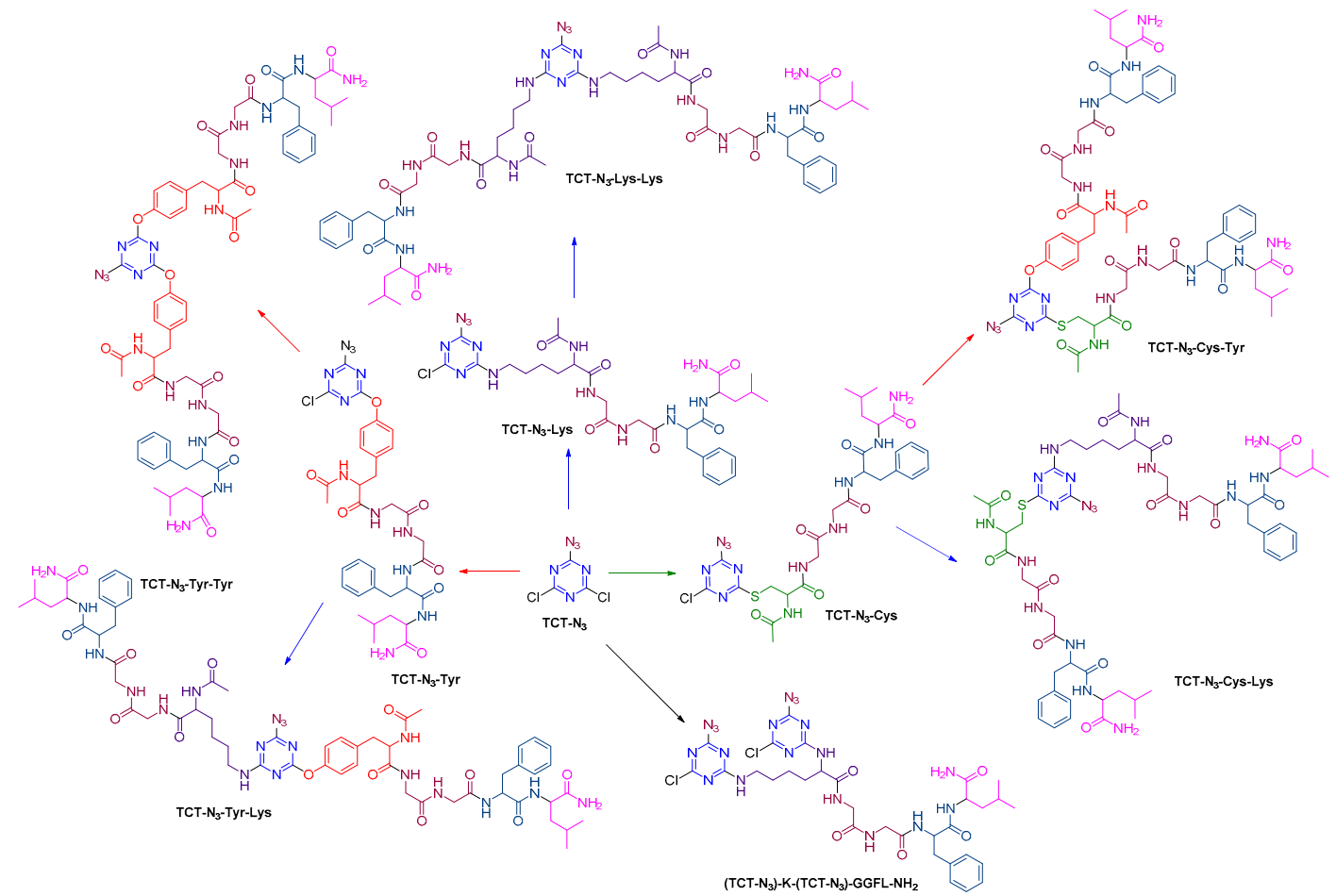

Scheme 8. Sequential incorporation of pentapeptides onto TCT-N 3 . 
The first incorporation of peptide was performed using an equimolar solution of TCT- $\mathrm{N}_{3}$ and peptide at $0{ }^{\circ} \mathrm{C}$ for $30 \mathrm{~min}$ in the presence of $\mathrm{K}_{2} \mathrm{CO}_{3}(\mathrm{pH}>8)$ as base, using $\mathrm{H}_{2} \mathrm{O}: \mathrm{ACN}(2: 1)$ as the solvent mixture. The reaction mixture was extracted using ethyl acetate (to remove any unreacted TCT- $\mathrm{N}_{3}$ ) to afford pure TCT- $\mathrm{N}_{3}-\mathrm{Lys}$, TCT- $\mathrm{N}_{3}-\mathrm{Cys}$, and TCT-N ${ }_{3}$-Tyr. With the high selectivity of $\mathrm{NH}$, as demonstrated earlier, TCT-N ${ }_{3}$-Lys was reacted with an equivalent of Lys peptide using $\mathrm{K}_{2} \mathrm{CO}_{3}$ as base at rt. The reaction was completed in 4 days, as monitored by HPLC. TCT- $\mathrm{N}_{3}-\mathrm{Cys}$ and TCT- $\mathrm{N}_{3}-\mathrm{Tyr}$ were reacted with Lys and Tyr under the same conditions. TCT- $\mathrm{N}_{3}-\mathrm{Cys}-\mathrm{Lys}$ and TCT-N $\mathrm{N}_{3}-\mathrm{Cys}-\mathrm{Tyr}$ formed in 2 days at rt. TCT- $\mathrm{N}_{3}$-Tyr-Lys and TCT- $\mathrm{N}_{3}$-Tyr-Tyr formed at $\mathrm{rt}$ in $4 \mathrm{~h}$ and $8 \mathrm{~h}$, respectively. The reactivity of TCT- $\mathrm{N}_{3}$ with $\alpha$ and $\varepsilon \mathrm{NH}_{2}$ of Lys in H-KGGFL-NH $\mathrm{N}_{2}$ was also studied (Scheme 7). The different nucleophilicity of $\alpha$ and $\varepsilon \mathrm{NH}_{2}$ did not affect the incorporation order, as the reaction was observed to reach completion in $10 \mathrm{~min}$ at $0{ }^{\circ} \mathrm{C}$, forming TCT- $\mathrm{N}_{3}-\mathrm{K}\left(\mathrm{TCT}-\mathrm{N}_{3}\right)-\mathrm{GGFL}-\mathrm{NH}_{2}$, thereby demonstrating the high reactivity of amine toward TCT- $\mathrm{N}_{3}$.

\section{Executive Summary}

This report has two different parts. In the first one the biological activities of several libraries of s-triazine-based compounds is discussed. In the second part, different tips for the preparation of these substituted s-triazines based in the tri-orthogonal concept are covered.

Various s-triazine cores show therapeutic properties, including MAO-A and B inhibition, anticancer/ antiproliferative, and antileishmanial activity, and also antibacterial activity against MDR clinical isolates. They can also be used as drug nano-delivery systems. Some of the derivatives could be considered leads/hits for these targets. However, as in our example and the literature, the main nucleophile is amine $(\mathrm{NH})$, and in some cases alcohol $(\mathrm{OH})$.

The preferential order of incorporation of the different nucleophiles into the TCT core was found to be first alcohol, second thiol, and finally amine (but this order required a higher temperature especially for the replacement of the third $\mathrm{Cl}$ atom). Phenol (replacing alcohol) was used as a modifier in the TCT core, thereby removing the need for a higher temperature for the replacement of the third $\mathrm{Cl}$ atom (from reflux conditions to $35^{\circ} \mathrm{C}$ ). However, the applicability of phenol on the TCT core is restricted due to its limitation as the modifier for the first replacement.

Azide was another modifier used in TCT, and the tri-orthogonal chemoselectivity of the TCT core has been successfully demonstrated. Hence, the first replacement on TCT- $\mathrm{N}_{3}$ occurred at $0{ }^{\circ} \mathrm{C}$, and the last one at rt. Competitive studies show that amine $(\mathrm{NH})$ is highly selective in the presence of other nucleophiles, thereby making it a suitable linker for the protein/peptide conjugation. The use of azide as a modifier alongside two nucleophile ( $\mathrm{SH}$ and $\mathrm{pOH}$ ) substitutions can take place in any order at rt (a condition that is favorable for proteins/peptides).

\section{Future Perspectives}

This review reveals s-triazine as an excellent privileged heterocyclic core with a broad therapeutic application. Its privileged structure, related to the starting materials 1,3,5trichloro-2,4,6-triazine (also known as cyanuric chloride), and its commercial availability, well-defined nature, low cost, and ubiquity in biological applications makes it a unique core for several applications.

The ability of TCT to undergo sequential nucleophilic substitution using regular nucleophiles (first $\mathrm{Cl}$ atom replacement at $0{ }^{\circ} \mathrm{C}$, second at $\mathrm{rt}$, and third at $>90^{\circ} \mathrm{C}$ ) allows chemists to control the organic structure and make it react in the required condition for achieving each given objective. However, the last replacement at a higher temperature explains the poor diversity of TCT and limits its applicability. The use of TCT as a linker with modifiers will broaden the synthesis of derivatives under biologically favorable conditions in several medicinal chemistry projects. 
Orthogonality and chemoselectivity are two concepts of modern organic chemistry that have been exploited in various fields of research, ranging from supramolecular to organic/bioconjugation chemistry. Although orthogonality is a subset of chemoselectivity, we have demonstrated the fusion of these two concepts as "Orthogonal Chemoselectivity" using TCT and defined this new concept as a "discrimination between reactive sites in any order". The application of this concept in medicinal chemistry programs will allow for the preparation of a wide range of TCT derivatives in which other substituents can be present along with $\mathrm{N}$-substitution, thereby broadening the applicability of TCT in this field.

In the current scenario, the loss of antibodies during the synthesis of Antibody Drug Conjugates (ADCs) occurs during disulfide cleavage for the bioconjugation of thiols with the linkers currently available $[37,38]$. ADCs also suffer from premature cleavage due to stability issues of the thioether bond [39]. With the successful fine-tuning of reaction conditions with modifiers, TCT- $\mathrm{N}_{3}$ can be exploited as a linker in the construction of Peptide Drug Conjugates/Antibody Drug Conjugates (PDCs/ADCs) [37,38,40]. The presence of several functionalities (amine, thiol, phenol) in peptides and proteins does not limit the use of the TCT core due to the high selectivity of amine in the presence of other nucleophiles, which opens the possibility of using them as linkers for protein/peptides bio-conjugation, with a further extension to antibodies.

Author Contributions: The strategy was designed by A.S., B.G.d.1.T., A.E.-F. and F.A. The manuscript was written by A.S. with the help of R.S. All authors have read and agreed to the published version of the manuscript.

Funding: The work was funded in part by the National Research Foundation (NRF) (\# 105892 and Blue Sky's Research Programme \# 120386). The authors extend their appreciation to the International Scientific Partnership Program ISPP at King Saud University (ISPP\# 0061), Saudi Arabia.

Institutional Review Board Statement: Not applicable.

Informed Consent Statement: Not applicable.

Data Availability Statement: No new data were created or analyzed in this study. Data sharing is not applicable to this article.

Acknowledgments: The authors extended their appreciation to the National Research Foundation (NRF) (\# 105892 and Blue Sky's Research Programme \# 120386), and the International Scientific Partnership Program ISPP at King Saud University (ISPP\# 0061), Saudi Arabia for funding this work. Rotimi Sheyi thanks MINTEK (South Africa) for a predoctoral fellowship.

Conflicts of Interest: The authors declare no conflict of interest.

\section{References}

1. Bozorov, K.; Zhao, J.; Aisa, H.A. 1,2,3-Triazole-containing hybrids as leads in medicinal chemistry: A recent overview. Bioorg. Med. Chem. 2019, 27, 3511-3531. [CrossRef] [PubMed]

2. Moon, H.-S.; Jacobson, E.M.; Khersonsky, S.M.; Luzung, M.R.; Walsh, D.P.; Xiong, W.; Lee, J.W.; Parikh, P.B.; Lam, J.C.; Kang, T.-W.; et al. A Novel Microtubule Destabilizing Entity from Orthogonal Synthesis of Triazine Library and Zebrafish Embryo Screening. J. Am. Chem. Soc. 2002, 124, 11608-11609. [CrossRef]

3. Shah, D.R.; Modh, R.P.; Chikhalia, K.H. Privileged s-triazines: Structure and pharmacological applications. Future Med. Chem. 2014, 6, 463-477. [CrossRef] [PubMed]

4. Mooibroek, T.J.; Gamez, P. The s-triazine ring, a remarkable unit to generate supramolecular interactions. Inorganica Chim. Acta 2007, 360, 381-404. [CrossRef]

5. Singla, P.; Luxami, V.; Paul, K. Triazine as a promising scaffold for its versatile biological behavior. Eur. J. Med. Chem. 2015, 102, 39-57. [CrossRef]

6. Blotny, G. Recent applications of 2, 4, 6-trichloro-1, 3, 5-triazine and its derivatives in organic synthesis. Tetrahedron 2006, 62, 9507-9522. [CrossRef]

7. Smolin, E.M.; Rapoport, L. s-Triazines and Derivatives; John Wiley \& Sons: Hoboken, NJ, USA, 2009 ; Volume 26.

8. Sharma, A.; El-Faham, A.; de la Torre, B.G.; Albericio, F. Exploring the orthogonal chemoselectivity of 2,4,6-trichloro-1,3,5-triazine (TCT) as a trifunctional linker with different nucleophiles: Rules of the game. Front. Chem. 2018, 6, 516. [CrossRef]

9. Sheyi, R.; Sharma, A.; El-Faham, A.; de la Torre, B.G.; Albericio, F. Phenol as a Modulator in the Chemical Reactivity of 2,4,6-Trichloro-1,3,5-triazine: Rules of the Game II*. Aust. J. Chem. 2020, 73, 352-356. [CrossRef] 
10. Bork, J.T.; Lee, J.W.; Khersonsky, S.M.; Moon, H.-S.; Chang, Y.-T. Novel Orthogonal Strategy toward Solid-Phase Synthesis of 1,3,5-Substituted Triazines. Org. Lett. 2003, 5, 117-120. [CrossRef]

11. Figg, C.A.; Kubo, T.; Sumerlin, B.S. Efficient and chemoselective synthesis of $\omega, \omega$-heterodifunctional polymers. ACS Macro Lett. 2015, 4, 1114-1118. [CrossRef]

12. Kubo, T.; Figg, C.A.; Swartz, J.L.; Brooks, W.L.A.; Sumerlin, B.S. Multifunctional Homopolymers: Postpolymerization Modification via Sequential Nucleophilic Aromatic Substitution. Macromolecules 2016, 49, 2077-2084. [CrossRef]

13. El-Faham, A.; Soliman, S.M.; Ghabbour, H.A.; Elnakady, Y.A.; Mohaya, T.A.; Siddiqui, M.R.H.; Albericio, F. Ultrasonic promoted synthesis of novel s-triazine-Schiff base derivatives; molecular structure, spectroscopic studies and their preliminary antiproliferative activities. J. Mol. Struct. 2016, 1125, 121-135. [CrossRef]

14. Sharma, A.; Ghabbour, H.; Khan, S.T.; de la Torre, B.G.; Albericio, F.; El-Faham, A. Novel pyrazolyl-s-triazine derivatives, molecular structure and antimicrobial activity. J. Mol. Struct. 2017, 1145, 244-253. [CrossRef]

15. Sharma, A.; Jad, Y.; Siddiqui, M.R.H.; de la Torre, B.G.; Albericio, F.; El-Faham, A. Synthesis, characterization and tautomerism of 1,3-dimethyl pyrimidine-2,4,6-trione-s-triazinyl hydrazine/hydrazone derivatives. J. Chem. 2017, 1-10. [CrossRef]

16. Sharma, A.; Sheyi, R.; Kumar, A.; El-Faham, A.; de la Torre, B.G.; Albericio, F. Investigating Triorthogonal Chemoselectivity. Effect of Azide Substitution on the Triazine Core. Org. Lett. 2019, 21, 7888-7892. [CrossRef]

17. Liu, H.; Long, S.; Rakesh, K.P.; Zha, G.-F. Structure-activity relationships (SAR) of triazine derivatives: Promising antimicrobial agents. Eur. J. Med. Chem. 2020, 185, 111804. [CrossRef]

18. Cascioferro, S.; Parrino, B.; Spanò, V.; Carbone, A.; Montalbano, A.; Barraja, P.; Diana, P.; Cirrincione, G. 1,3,5-Triazines: A promising scaffold for anticancer drugs development. Eur. J. Med. Chem. 2017, 142, 523-549. [CrossRef]

19. Li, J.; Wang, S.; Liao, L.; Ma, Q.; Zhang, Z.; Fan, G. Stabilization of an intramolecular hydrogen-bond block in an s-triazine insensitive high-energy material. New J. Chem. 2019, 43, 10675-10679. [CrossRef]

20. Simanek, E.E.; Abdou, H.; Lalwani, S.; Lim, J.; Mintzer, M.; Venditto, V.J.; Vittur, B. The 8 year thicket of triazine dendrimers: Strategies, targets and applications. Proc. Math. Phys. Eng. Sci. 2009, 466, 1445-1468. [CrossRef]

21. Khattab, S.N.; Khalil, H.H.; Bekhit, A.A.; Abd El-Rahman, M.M.; El-Faham, A.; Albericio, F. Synthesis and preliminary biological evaluation of 1,3,5-triazine amino acid derivatives to study their MAO inhibitors. Molecules 2015, 20, 15976-15988. [CrossRef]

22. Khattab, S.N.; Khalil, H.H.; Bekhit, A.A.; Abd El-Rahman, M.M.; de la Torre, B.G.; El-Faham, A.; Albericio, F. 1,3,5-triazino peptide derivatives: Synthesis, characterization, and preliminary antileishmanial activity. ChemMedChem 2018, 13, 725-735. [CrossRef]

23. Farooq, M.; Sharma, A.; Almarhoon, Z.; Al-Dhfyan, A.; El-Faham, A.; Taha, N.A.; Wadaan, M.A.M.; Torre, B.G.d.l.; Albericio, F. Design and synthesis of mono-and di-pyrazolyl-s-triazine derivatives, their anticancer profile in human cancer cell lines, and in vivo toxicity in zebrafish embryos. Bioorg. Chem. 2019, 87, 457-464. [CrossRef]

24. Al Rasheed, H.; Dahlous, K.; Sharma, A.; Sholkamy, E.; El-Faham, A.; de la Torre, B.G.; Albericio, F. Barbiturate- and Thiobarbituarte-Based s-Triazine Hydrazone Derivatives with Promising Antiproliferative Activities. ACS Omega 2020, 5, 15805-15811. [CrossRef] [PubMed]

25. El-Faham, A.; Farooq, M.; Almarhoon, Z.; Abd Alhameed, R.; Wadaan, M.A.M.; de la Torre, B.G.; Albericio, F. Di- and tri-substituted s-triazine derivatives: Synthesis, characterization, anticancer activity in human breast-cancer cell lines, and developmental toxicity in zebrafish embryos. Bioorg. Chem. 2020, 94, 103397. [CrossRef]

26. Sheyi, R.; Sharma, A.; Kumar, A.; El-Faham, A.; De la Torre, B.G.; Albericio, F. 1, 3, 5-Triazine as core for the preparation of dendrons. Arkivoc 2020. [CrossRef]

27. Khattab, S.N.; Abdel Naim, S.E.; El-Sayed, M.; El Bardan, A.A.; Elzoghby, A.O.; Bekhit, A.A.; El-Faham, A. Design and synthesis of new s-triazine polymers and their application as nanoparticulate drug delivery systems. New J. Chem. 2016, 40, 9565-9578. [CrossRef]

28. Ramadan, D.R.; Elbardan, A.A.; Bekhit, A.A.; El-Faham, A.; Khattab, S.N. Synthesis and characterization of novel dimeric s-triazine derivatives as potential anti-bacterial agents against MDR clinical isolates. New J. Chem. 2018, 42, 10676-10688. [CrossRef]

29. Sharma, A.; Kumar, A.; El-Faham, A.; de la Torre, B.G.; Albericio, F. Exploiting azido-dichloro-triazine as a linker for regioselective incorporation of peptides through their N, O, S functional groups. Bioorg. Chem. 2020, 104, 104334. [CrossRef]

30. Abd Alhameed, R.; Almarhoon, Z.; N. Sholkamy, E.; Ali Khan, S.; Ul-Haq, Z.; Sharma, A.; G. de la Torre, B.; Albericio, F.; El-Faham, A. Novel 4,6-Disubstituted s-Triazin-2-yl Amino Acid Derivatives as Promising Antifungal Agents. J. Fungi 2020, 6, 237. [CrossRef] [PubMed]

31. Barany, G.; Merrifield, R. A new amino protecting group removable by reduction. Chemistry of the dithiasuccinoyl (Dts) function. J. Am. Chem. Soc. 1977, 99, 7363-7365. [CrossRef] [PubMed]

32. Barany, G.; Albericio, F. Three-dimensional orthogonal protection scheme for solid-phase peptide synthesis under mild conditions. J. Am. Chem. Soc. 1985, 107, 4936-4942. [CrossRef]

33. Trost, B.M. Selectivity: A key to synthetic efficiency. Science 1983, 219, 245-250. [CrossRef]

34. Bucher, G.; Siegler, F.; Wolff, J.J. Photochemistry of 2-azido-4, 6-dichloro-s-triazine: Matrix isolation of a strained cyclic carbodiimide containing four nitrogen atoms in a seven-membered ring. Chem. Comm. 1999, 20, 2113-2114. [CrossRef]

35. Malkov, G.V.; Shastin, A.V.; Estrin, Y.I.; Badamshina, E.R.; Mikhailov, Y.M. Synthesis and Characterization of the Nitrogen-Rich Hyperbranched Polymers-Poly ([1, 2, 3]-Triazole-[1, 3, 5]-Triazine)s. Propellants Explos. Pyrotech. 2008, 33, 431-436. [CrossRef] 
36. Takayama, Y.; Kusamori, K.; Nishikawa, M. Click Chemistry as a Tool for Cell Engineering and Drug Delivery. Molecules 2019, 24, 172. [CrossRef]

37. Böhme, D.; Beck-Sickinger, A.G. Drug delivery and release systems for targeted tumor therapy. J. Pept. Sci. 2015, 21, 186-200. [CrossRef] [PubMed]

38. Lu, J.; Jiang, F.; Lu, A.; Zhang, G. Linkers Having a Crucial Role in Antibody-Drug Conjugates. Int. J. Mol. Sci. 2016, 17, 561. [CrossRef]

39. Tumey, L.N.; Charati, M.; He, T.; Sousa, E.; Ma, D.; Han, X.; Clark, T.; Casavant, J.; Loganzo, F.; Barletta, F.; et al. Mild Method for Succinimide Hydrolysis on ADCs: Impact on ADC Potency, Stability, Exposure, and Efficacy. Bioconjug. Chem. 2014, 25, 1871-1880. [CrossRef]

40. Beck, A.; Goetsch, L.; Dumontet, C.; Corvaïa, N. Strategies and challenges for the next generation of antibody-drug conjugates. Nat. Rev. Drug Discov. 2017, 16, 315-337. [CrossRef] 